\title{
Influence of the protein content of boar seminal plasma on spermatozoa viability, motility and acrosome integrity in diluted semen stored for 3 days
}

\author{
J. Apić ${ }^{1,4}$, I. Stančić ${ }^{2}$, S. Vakanjac ${ }^{3}$, I. Radović ${ }^{2}$, A. Milovanović ${ }^{1}$, T. Barna ${ }^{1}$, M. Maletić ${ }^{3}$ \\ ${ }^{1}$ Department of Animal Reproduction, Scientific Veterinary Institute, Novi Sad, Serbia. \\ ${ }^{2}$ Department of Veterinary Medicine, Faculty of Agriculture, University of Novi Sad, Novi Sad, Serbia. \\ ${ }^{3}$ Department of Reproduction, Fertility and Artificial Insemiantion, Faculty of Veterinary Medicine, \\ University of Belgrade, Belgrade, Serbia.
}

\begin{abstract}
The aim of the present study was to investigate the influence of the protein content of seminal plasma on the motility, viability and acrosome integrity of spermatozoa in extended semen stored for 3 days. A total of 32 semen samples (from four boars) with high $(4 \mathrm{mg} / \mathrm{ml})$ and 32 semen samples (from four boars) with low $(2 \mathrm{mg} / \mathrm{ml})$ protein content were investigated. The semen samples were diluted by BTS at a ratio of $1: 4$, and stored for $72 \mathrm{~h}$ at $17^{\circ} \mathrm{C}$. The percentages of live sperm (LS), live sperm with damaged acrosome (LDA) and total sperm with damaged acrosome (TDA) were detected by flow cytometry. Sperm progressive motility (PM) was detected using CASA. After $72 \mathrm{~h}$ of storage, the percentage of LS and PM was significantly $(\mathrm{P}<0.01)$ higher, and the LDA and TDA were significantly $(\mathrm{P}<0.01)$ lower in samples with high protein content than in the samples with low protein content ( $\mathrm{LS}=66$ vs. $44 \%, \mathrm{PM}=64$ vs. $48 \%$, LDA $=15$ vs. $21 \%$ and $\mathrm{TDA}=29$ vs. $45 \%$, respectively). When comparing the difference between 0 and $72 \mathrm{~h}$ of storage, the percentage decrease in LS and PM, while increase in LDA and TDA were significantly higher in the samples with low (LS: 75 to $44 \%$; PM: 68 to $48 \%$; LDA: 11 to $21 \%$ and TDA: 23 to $45 \%$ ) than in the samples with high protein content (LS: 78 to $66 \%$; PM: 70 to $64 \%$; LDA: 9 to $15 \%$ and TDA: 17 to $29 \%$ ). We concluded that protein content in seminal plasma has a significant influence on progressive motility, viability and acrosome integrity in diluted semen stored for 3 days.
\end{abstract}

Keywords: boar, protein, semen, sperm, storage.

\section{Introduction}

Artificial insemination (AI) is the most important reproductive biotechnology for successful intensive pig production (Erikson et al., 2000; Gerrits et al., 2005). In this technology, the reproductive efficiency of expensive genetically superior boars has great economic importance (Gadea et al., 2005). This is often the reason for the extreme extension of ejaculate to produce more AI doses and/or prolonging the preservation time of extended liquid semen.
Unfortunately, extreme semen extension (Maxwell and Johnson, 1999; Bößenrodt et al., 2008; Lipenský et al., 2013) and/or the in vitro preservation of extended liquid boar semen for a longer time, i.e. 3 to 5 days (Alexopoulos et al., 1996; Boe-Hansen et al., 2005; Barrabés et al., 2008; Waberski et al., 2011; Stančić et al., 2012) is the most common reason for a gradual decline in sperm quality and fertility. Consequently, it is often the reason for a reduced fertility rate in artificially inseminated sows. In fact, it has been shown that artificial insemination by AI doses, obtained from extremely extended ejaculates, often results in lower fertility rates than those obtained by naturally mated sows (Tummaruk et al., 2000; Tanavots et al., 2002; Gadea, 2005; Alm et al., 2006, Stančić et al., 2009).

Procedures involving the in vitro handling and preservation of liquid boar semen promote a decrease in sperm progressive motility, as well as damage to the acrosome and sperm plasma membranes (Kommisurd et al., 2002; Maxwell et al., 2007; Bößenrodt et al., 2008; Gączarzewicz et al., 2010; Stančić et al., 2012; González-Cadavid et al., 2014). Namely, it has been shown that a reduction in the protein concentration, as a result of seminal plasma dilution, plays a key role in decreasing the fertility of stored liquid semen (Maxwell and Johnson, 1999; Mogielnicka-Brzozowska and Kordan, 2011; Nasrin and Calogero, 2012; GonzálezCadavid et al., 2014). The average total protein content in boar seminal plasma is approximately $4 \%$. Namely, Moore and Hibbit (1976) found an average 3.9\% of total protein in boar seminal plasma, and Frunză et al. (2008) refer that this value range from 3.26 to $4.0 \%$. In our recent investigation (Apić et al. 2015), that included 106 boars, it was been demonstrated that average protein content in seminal plasma was $2.9 \%$, and ranged from 1.25 to $6.50 \%$. However, it has been found that ejaculates with the highest protein levels in seminal plasma exhibit the highest farrowing rates and greatest number of live born piglets, compared with ejaculates that have lower levels of protein (Flowers, 2001; Novak et al., 2010).

Therefore, the aim of the present study was to determine the influence of protein content in the native seminal plasma on the sperm motility and acrosome integrity in diluted semen after storage for 3 days. 


\section{Materials and Methods}

\section{Farm and animals}

The experiment was conducted at a commercial pig farm in Serbia with 1,000 sows in the breeding herd. The farm is approximately $10 \mathrm{~km}$ from the laboratory where the semen quality control was performed.

Four AI boars (two Landrace and two Large White) with high (4.1\%) and four boars (two Landrace and two Large White) with low $(2.2 \%)$ protein content in their seminal plasma, aged between 18 and 36 months, were allocated to the trial. The boars were selected based on the previously determined concentration of protein in the seminal plasma of eight ejaculates from each boar.

\section{Semen preparation at the farm}

Eight ejaculates were collected per boar (one ejaculate per week). Thus, 32 ejaculates were obtained from the four boars with high protein content, and 32 ejaculates from the four boars with low protein content in their seminal plasma. A gel-free spermatic and postspermatic semen fraction was collected from each boar, using the gloved hand method. Gel-fraction was separated by a sterile disposable filter. Immediately after collection the semen was filtered through gauze, and the quality parameters of the ejaculate were evaluated, as is the usual practice at the farm. In the experiment only ejaculates with a volume of 190 to $310 \mathrm{ml}$, a spermatozoa concentration from $200 \times 10^{6} / \mathrm{ml}$ to $300 \times 10^{6} / \mathrm{ml}$ and progressive motility $\geq 65 \%$ were included. The ejaculate quality parameters (volume, concentration, total number and progressive motility of spermatozoa) were not significantly different $(\mathrm{P}>0.05)$ between the boars with high and those with low protein content in their seminal plasma. Thus, the proportion of spermatozoa concentration and protein content per unit volume of seminal plasma was similar in each sample tested. However, the protein content of the seminal plasma was significantly different $(\mathrm{P}<0.01)$ between the two groups of boars (4.1 vs. 2.2\%; Table 1).

Table 1. Sperm quality parameters assessed in native sperm samples (mean \pm SD)

\begin{tabular}{lcc} 
& $\begin{array}{c}\text { High protein content } \\
(\mathrm{n}=32)\end{array}$ & $\begin{array}{c}\text { Low protein content } \\
(\mathrm{n}=32)\end{array}$ \\
\hline Protein content in seminal plasma $(\%)$ & $4.1 \pm 0.25^{\mathrm{A}}(3.5-4.7)$ & $2.2 \pm 0.30^{\mathrm{B}}(1.5-2.6)$ \\
Ejaculate volume $(\mathrm{ml})$ & $249 \pm 36^{\mathrm{a}}$ & $240 \pm 23^{\mathrm{a}}$ \\
Spermatozoa concentration $\left(\times 10^{6} / \mathrm{ml}\right)$ & $277 \pm 33^{\mathrm{a}}$ & $269 \pm 25^{\mathrm{a}}$ \\
Total number of spermatozoa $\left(\times 10^{9}\right)$ & $68 \pm 12.5^{\mathrm{a}}$ & $63 \pm 8.7^{\mathrm{a}}$ \\
Progressive motility $(\%)$ & $81 \pm 4.1^{\mathrm{a}}$ & $78 \pm 4.5^{\mathrm{a}}$ \\
\hline
\end{tabular}

Values with a different superscript, within a row, differ $\left({ }^{\mathrm{AB}} \mathrm{P}<0.01 ;{ }^{\mathrm{ab}} \mathrm{P}<0.05\right)$.

After evaluating the quality of the ejaculate, one $10 \mathrm{ml}$ of fresh gel-free semen sample, and one sample of the same volume, but extended with BTS Beltsville Thawing Solution (Minitüb, Germany) at exactly 1:4 rate, were prepared from each ejaculate. The semen samples were placed in sterile plastic tubes with caps and stored in a thermo-box at $17^{\circ} \mathrm{C}$. They were then transported to the laboratory at the Scientific Veterinary Institute in Novi Sad, Serbia, within 2-3 h of semen collection at the farm, for semen quality assessment.

\section{Semen quality assessment in the laboratory}

Immediately after arrival in the laboratory, the semen samples were reactivated in a water bath at $35^{\circ} \mathrm{C}$ for $30 \mathrm{~min}$ before the testing began. The native semen samples were tested for spermatozoa concentration $\left(\times 10^{6} / \mathrm{ml}\right)$, total number of spermatozoa in the ejaculate $\left(\times 10^{9}\right)$ and progressive motility (\%) using CASA Computer Assisted Sperm Analysis (ISAS Proiser, Paterna, Spain) with an integrated software system for the sperm analysis (ISAS) and a USB 200i light microscope (Proiser, Paterna, Spain) at $100 \mathrm{X}$ magnification.

Diluted semen samples (1:4 dilution ratio) were prepared from the ejaculates with a high (average $4.1 \mathrm{mg} / \mathrm{ml}$ ) and a low (average $2.2 \mathrm{mg} / \mathrm{ml}$ ) content of protein in their seminal plasma. From each sample, spermatozoa were evaluated for acrosome damage and spermatozoa progressive motility immediately after arrival at the laboratory $(0 \mathrm{~h})$ and after storage for $72 \mathrm{~h}$ at $17^{\circ} \mathrm{C}$. The acrosome status was evaluated using flow cytometry (Guava Milipore-IMV, USA). A combination of fluorometric colors Lectin PNA, Alexa Flour ${ }^{\circledR} 488$ conjugate (Life technologies, Carlsbad, CA, USA) and propidium iodide (Life technologies, Carlsbad, CA,USA) was used for assessing the acrosome status.

To prepare the samples for acrosome status testing: (1) fluorometric colors $(2 \mu \mathrm{l}$ propidium iodide and $1 \mu \mathrm{l}$ Lectin PNA) were placed in a closed plastic Eppendorf tube; (2) $97 \mu$ l EasyBuffer A - Swine (IMVtechnologies) was added to the Eppendorf tube; (3) followed by $8 \mu \mathrm{l}$ fresh semen; and (4) another $292 \mu \mathrm{l}$ EasyBuffer was added to the Eppendorf tube. This procedure lasted for about $1 \mathrm{~min}$. The samples were incubated for $10 \mathrm{~min}$ at $37^{\circ} \mathrm{C}$ in a thermo-mixer for better homogenisation. After incubation, a flow cytometry device was used to read the results. Progressive motility $(\%)$ in the diluted semen was evaluated using CASA - Computer Assisted Sperm 
Analysis (ISAS Proiser, Spain), as described above. The sperm cells were assessed as having normal or altered acrosomes. The acrosomal alterations were expressed as a percentage of sperm cells with normal status. Progressive motility was expressed as a percentage of the total number of sperm cells. Taking the value of each parameter (Live spermatozoa-LS, Progressive motility-PM, Live spermatozoa with damaged acrosomes-LDA and Total spermatozoa with damaged acrosomes-TDA) as $100 \%$ at the beginning of testing $(0 \mathrm{~h})$, the percentage differences between the initial values and those after $72 \mathrm{~h}$ of storage were calculated for the samples with high and low protein content.

\section{Analysis of protein content in seminal plasma}

After arrival in the laboratory, the fresh gel-free semen samples $(20 \mathrm{ml})$ were centrifuged at $1000 \times \mathrm{g}$ for $10 \mathrm{~min}$ at $4^{\circ} \mathrm{C}$, to separate the spermatozoa from the seminal plasma. The supernatant was re-centrifuged at $3000 \times \mathrm{g}$ for $15 \mathrm{~min}$ at $4^{\circ} \mathrm{C}$ to purify the seminal plasma from the residual sperm and other organic particles. The seminal plasma samples obtained were placed in plastic tubes with caps, and stored in a refrigerator at $4^{\circ} \mathrm{C}$. The total protein content of the seminal plasma was determined by the AOAC chemical method (Official Method 2001.11, Büchi Device). The analysis was performed within 4 to $6 \mathrm{~h}$ after collecting the ejaculate at the farm.

\section{Statistical analysis}

Data on the percentage value of spermatozoa motility and acrosome integrity assessments, expressed as a number of good spermatozoa number/total spermatozoa number $\times 100$, were analyzed by the Fischer's egzact test. The data were analyzed by the Statistics 12 software package (StatSoft Inc., Tulsa, OK, USA). The mean \pm standard deviation values of the experimental data are presented in Tables 1 and 2.

\section{Results}

The average total live number of spermatozoa (LS), progressive motility (PM), live spermatozoa with damaged acrosomes (LDA) and total spermatozoa with damaged acrosomes (TDA) in the diluted semen samples with high or low protein content, after 0 and $72 \mathrm{~h}$ of storage, are shown in Table 2. The percentages of LS and PM were significantly $(\mathrm{P}<0.01)$ lower, while LDA and TDA were significantly $(\mathrm{P}<0.01)$ higher after storage for $72 \mathrm{~h}$, than those at the start of the test $(0 \mathrm{~h})$, both for the samples with a high ( $\mathrm{LS}=78: 66 \%, \mathrm{PM}=70: 64 \%$, $\mathrm{LDA}=9: 15 \%$ and TDA $=17: 29 \%$, respectively) and low protein content $(\mathrm{LS}=75: 44 \%, \mathrm{PM}=68: 48 \%$, $\mathrm{LDA}=11: 21 \%$ and $\mathrm{TDA}=23: 45 \%$ ).

The percentage differences between all of the values tested at 0 and $72 \mathrm{~h}$ of storage, with high or low protein content in the seminal plasma, were significantly $(\mathrm{P}<0.01)$ greater in the samples with low protein content than the samples with high protein content. Namely, the percentage of LS decreased by $14.4 \%$ in the high protein samples, and by $40.6 \%$ in the low protein samples. Progressive motility decreased by $9.4 \%$ in the high and by $31.7 \%$ in the low protein samples. The percentage of LDA increased by $64.6 \%$ in the high and by $93.8 \%$ in the low protein samples, while the percentage of LDA increased by $64.6 \%$ in the high and by $93.8 \%$ in the low protein samples (Table 2).

Table 2. Sperm motility and acrosome status assessed at 0 and $72 \mathrm{~h}$ in diluted semen samples (mean $\pm \mathrm{SD}$ )

\begin{tabular}{|c|c|c|c|c|}
\hline & \multicolumn{4}{|c|}{ Protein content in seminal plasma } \\
\hline & & $1 \%)$ & Lo & $(2.2 \%)$ \\
\hline & \multicolumn{4}{|c|}{ Diluted semen storage time* } \\
\hline & $0 \mathrm{~h}$ & $72 \mathrm{~h}$ & $0 \mathrm{~h}$ & $72 \mathrm{~h}$ \\
\hline Total ejaculate samples tested (n) & \multicolumn{2}{|c|}{32} & \multicolumn{2}{|c|}{32} \\
\hline Live spermatozoa - LS (\%) & \multicolumn{2}{|c|}{$\begin{array}{c}78^{\mathrm{AX}} \pm 5.4 \quad 66^{\mathrm{BZ}} \pm 6.2 \\
\left(-14.4 \pm 4.6^{\mathrm{X}}\right)\end{array}$} & \multicolumn{2}{|c|}{$\begin{array}{c}75^{\mathrm{AY}} \pm 4.1 \quad 44^{\mathrm{BI}} \pm 2.0 \\
\left(-40.6 \pm 3.7^{\mathrm{Y}}\right)\end{array}$} \\
\hline Progressive motility - PM (\%) & \multicolumn{2}{|c|}{$\begin{array}{c}70 \pm 8.92^{\mathrm{AX}} \\
\left(-9.4 \pm 6.4^{\mathrm{X}}\right)\end{array}$} & \multicolumn{2}{|c|}{$\begin{array}{c}68 \pm 5.28^{\mathrm{AY}} \quad 48 \pm 10.49^{\mathrm{BI}} \\
\left(-31.7 \pm 7.2^{\mathrm{Y}}\right)\end{array}$} \\
\hline \multirow{2}{*}{$\begin{array}{l}\text { Live spermatozoa with damaged } \\
\text { acrosomes - LDA (\%) }\end{array}$} & $9.1^{\mathrm{Ax}} \pm 1.9$ & $14.8^{\mathrm{BZ}} \pm 2.4$ & $11.1^{\mathrm{Ay}} \pm 3.9$ & $20.7^{\mathrm{BI}} \pm 6.5$ \\
\hline & \multicolumn{2}{|c|}{$\left(+64.6 \pm 2.4^{\mathrm{X}}\right)$} & \multicolumn{2}{|c|}{$\left(+93.8 \pm 4.7^{\mathrm{Y}}\right)$} \\
\hline \multirow{2}{*}{$\begin{array}{l}\text { Total spermatozoa with damaged } \\
\text { acrosomes - TDA (\%) }\end{array}$} & $17.6^{\mathrm{AX}} \pm 3.3$ & $29.0^{\mathrm{BZ}} \pm 5.8$ & $22.7^{\mathrm{AY}} \pm 3.8$ & $44.7^{\mathrm{BI}} \pm 9.1$ \\
\hline & \multicolumn{2}{|c|}{$\left(+63.6 \pm 4.5^{\mathrm{X}}\right)$} & $(+92.5$ & $\left.6.7^{\mathrm{Y}}\right)$ \\
\hline
\end{tabular}

Values with a different superscript, within a row and the same protein content, $\operatorname{differ}\left({ }^{\mathrm{AB}} \mathrm{P}<0.01 ;{ }^{\mathrm{ab}} \mathrm{P}<0.05\right)$; Values without a common superscript, for different protein content and $0 \mathrm{~h}$ of storage, differ $\left({ }^{\mathrm{XY}} \mathrm{P}<0.01 ;{ }^{\mathrm{xy}} \mathrm{P}<\right.$ $0.05)$; Values without a common superscript, for different protein content and $72 \mathrm{~h}$ of storage, $\operatorname{differ}\left({ }^{\mathrm{ZI}} \mathrm{P}<0.01\right.$; ${ }^{\mathrm{zi}} \mathrm{P}$ $<0.05$ ). In parentheses: Percentage differences between values at 0 and $72 \mathrm{~h}$ of storage within high or low protein content in the seminal plasma. 


\section{Discussion}

The results of this study show that the mean live spermatozoa (LS) and spermatozoa progressive motility $(\mathrm{PM})$ were significantly higher $(\mathrm{P}<0.01)$, and live spermatozoa with damaged acrosomes (LDA) and total spermatozoa with damaged acrosomes (TDA) were significantly lower $(\mathrm{P}<0.01)$, after storage for $72 \mathrm{~h}$ in the diluted semen samples with high protein content than the samples with low protein content. Furthermore, taking the starting $(0 \mathrm{~h})$ values as $100 \%$, the percentage differences between the starting values $(0 \mathrm{~h})$ and those after storage for $72 \mathrm{~h}$ were significantly lower $(\mathrm{P}<0.01)$ in the samples with high protein content $(\mathrm{LS}=-14.4 \%$, $\mathrm{PM}=-9.4 \%, \mathrm{LDA}=+64.6 \%$ and $\mathrm{TDA}=+63.6 \%)$ than the samples with low protein content $(\mathrm{LS}=-40.6 \%, \mathrm{PM}$ $=-31.7 \%, \mathrm{LDA}=+93.8 \%$ and $\mathrm{TDA}=+92.5 \%)$. This decrease in the spermatozoa parameters could be due to the diluted semen being stored for a longer time, as previously shown by others (Waberski et al., 1994, 2011; Maxwell and Johnson, 1999; Čerovsky, 2005; Leahy and Gadella, 2011; Lipenský et al., 2013). The preservation of diluted liquid boar semen induces damages over the storage period (Waberski et al., 2011). Our results demonstrate that the decrease in acrosome integrity was significantly higher than spermatozoa motility after $72 \mathrm{~h}$ of storage. Similar results have been found by Kommisurd et al. (2002). In their study, there was a 94 to $78 \%$ decrease in acrosome integrity, while the decrease in spermatozoa motility was significantly lower ( 80 to $78 \%$ ) over 5 days of storage. Their results indicate that the acrosome is more susceptible to damage during storage than the organelles responsible for spermatozoa motility.

However, it has been shown that seminal plasma is important for maintenance of boar spermatozoa fertility in vitro (Maxwell et al., 2007; Wolf and Smital, 2009; Nasrin and Calogero, 2012; Stančić et al., 2012). Namely, it has been found that seminal plasma overextension reduces the sperm progressive motility and increases the number of spermatozoa with damaged acrosomes or disintegrated acrosomal membranes (Kommisurd et al., 2002; Maxwell et al., 2007; Gączarzewicz et al., 2010; Stančić et al., 2012; Chuita et al., 2014).

A study by Caballero et al. (2004) demonstrated that the addition of seminal plasma to highly extended spermatozoa significantly $(\mathrm{P}<0.05)$ increases their viability. Cremades et al. (2004) showed that the addition of seminal plasma to freezing extender has a significant effect on post-thaw sperm parameters compared to the control. Namely, the sperm motility $(57 \%)$, plasma membrane integrity (57\%), and acrosome membrane integrity (57\%) were significantly $(\mathrm{P}<0.05)$ higher in samples with seminal plasma, compared to the control (51, 50 and $49 \%$ respectively). In addition, it has been found that seminal plasma proteins play a key role in this phenomenon
(Kommisurd et al., 2002; Strzeżek et al., 2005; Caballero et al., 2008; Garcia et al., 2009; MogielnickaBrzozowska and Kordan, 2011; Karsani and Nathan, 2013). A reduction in the concentration of protein in seminal plasma, for example by ejaculate overextension, leads to a gradual reduction in progressive motility, the survival rate, acrosome integrity, and mitochondrial activity, which are important factors for the spermatozoa fertilizing ability (Maxwell and Johnson, 1999; Strzeżek et al., 2005; Garcia et al., 2006, 2009; Ashrafzadeh et al., 2013; González-Cadavid et al., 2014). It has been found that the addition of homologous high protein content seminal plasma to boar spermatozoa from ejaculates with a low protein content, results in a significant $(\mathrm{P}<0.01)$ increase in progressive motility (70\%) after storage for $72 \mathrm{~h}$, compared with samples that contained autologous seminal plasma (40\%; Stančić et al., 2012). Chuita et al. (2014) found a significant $(\mathrm{P}<0.01)$ effect of washing (6, 66 and $56 \%$ ) or not washing $(66,76$ and $68 \%)$ of the seminal plasma on motility, live spermatozoa and live spermatozoa with intact acrosomes, respectively. Furthermore, the results obtained by Flowers (1998) demonstrate that the concentration of seminal plasma proteins is highly correlated with in vitro boar semen fertility. A further study (Flowers, 2001) shows a significant correlation between two proteins $(26 \mathrm{kDa}, \mathrm{pI} 6.2$ and $55 \mathrm{kDa}, \mathrm{pI} 4.8)$ present in boar seminal plasma and the level of semen fertilizing potential. In this study, ejaculates with the highest protein levels in seminal plasma exhibited the highest farrowing rates $(86.7 \pm 3.4 \%)$ and greatest number of live born piglets $(11.2 \pm 0.3)$, compared with those with lower protein levels (farrowing rate $=78.4 \pm 3.1 \%$, number of live born pigs $=10.4 \pm 0.3)$. Based on these findings, Flowers (2001) concludes that quantification of these two proteins in seminal plasma can be used to provide a qualitative rank for boar fertility, prior to their use for the artificial insemination of sows.

In summary, it can be concluded that the values of progressive motility, live spermatozoa, and spermatozoa with intact acrosomes were significantly higher in the diluted samples with high, as opposed to those with low protein content in the seminal plasma, after storage for 3 days. These results support the suggestions of other authors that protein content in seminal plasma can be a useful tool for predicting the fertilizing potential of boar ejaculate. Further research should establish the precise mechanisms by which seminal plasma proteins act on spermatozoa fertility in vitro. It is also necessary to compare field fertility data in sows inseminated by AI doses produced from ejaculates with high and low protein content.

\section{References}

Alm K, Peltoniemi OAT, Koskinen E, Andersson M. 2006. Porcine field fertility with two different 
insemination doses and the effect of sperm morphology. Reprod Domest Anim, 41:210-213.

Alexopoulos C, Boscos C, Saratsis PH, Saoulidis C, Kyriakis S. 1996. The effect of storage time and number of spermatozoa per insemination dose on semen characteristics and fertilizing capacity of boar semen diluted with Beltsville TS (BTS) extender. Anim Sci, 62:599-604.

Apić J, Vakanjac S, Radović I, Kučević D, Jotanović S, Kanački Z, Stanković B. 2015. Proteingehalt im Samenplasma von Zuchtebern auf den Betrieben für intensive Schweineproduktion in Serbien [Protein content in boar seminal plasma on the intensive pig production farms in Serbia]. Züchtungskunde, 87:361-368.

Ashrafzadeh1 A, Karsani AS, Nathan S. 2013. Mammalian sperm fertility related proteins. Int $\mathrm{J}$ Med Sci, 10:1649-1657.

Barrabés S, Bouvier B, Gary B, Mear X. 2008. Evaluation of the functionality of cooled stored sperm with three commercial extenders. Theriogenology, 70:1392. Abstract.

Boe-Hansen BG, Ersbøll KA, Greve T, Christensen P. 2005. Increasing storage time of extended boar semen reduces sperm DNA integrity. Theriogenology, 63:2006-2019.

Bößenrodt K, Müller K, Stähr B. 2008. Effects of an increasing dilution rate on in-vitro quality of liquid preserved boar semen. Theriogenology, 70:1392-1393. Abstract.

Caballero I, Vazquez JM, Centurión F, RodríguezMartinez H, Parrilla I, Roca J, Cuello C, Martinez EA. 2004. Comparative effects of autologous and homologous seminal plasma on the viability of largely extended boar spermatozoa. Reprod Domest Anim, 39:370-375.

Caballero I, Vazquez MJ, García ME, Parrilla I, Roca J, Calvete JJ, Sanz L, Martínez AE. 2008. Major proteins of boar seminal plasma as a tool for biotechnological preservation of spermatozoa. Theriogenology, 70:1352-1355.

Chuita T, Biswas KR, Tamuli KM, Deka CB, Sinha S, Goswami J, Banikb S, Kayasth BR. 2014. Effect of holding of semen and washing of seminal plasma on quality and fertility of Hampshire boar semen preserved at liquid state. Anim Reprod Sci, 145:141-149.

Cremades T, Carvajal G, Hernandez M, Vazquez MJ, Martinez AE, Roca J. 2004. The addition of seminal plasma from individual boars to freezing extender can improve the post-thaw sperm survival. Reprod Fertil Dev, 16:167. Abstract.

Čeřovský J, Frydrychová S, Lustyková A, Rozkot $M$. 2005. Changes in boar semen with a high and low level of morphologically abnormal spermatozoa. Czech $J$ Anim Sci, 50:289-299.

Erikson BM, Rodriguez-Martinez H. 2000. Effect of freezing and thawing rates on the post-thaw viability of boar spermatozoa frozen in flat packs and maxi-straws. Anim Reprod Sci, 63:205-220.
Flowers WL. 1998. Boar fertility and artificial insemination. In: Proceedings of 15 th IPVC Congress, Birmingham, England, 1998. Birmingham: IPVC. pp. 45-51.

Flowers WL. 2001. Relationship between seminal plasma proteins and boar fertility. Swine News (USA), 6:1-4.

Frunză I, Cernescu H, Korodi G. 2008. Physical and chemical parameters of boar sperm. Lucrări Stiintifice Med Vet (Timisoara, Romania), 41:634-640.

Gączarzewicz D, Piasecka M, Udała J, Błaszczyk B, Stankiewicz T, Laszczyńska M. 2010. Plasma membrane changes during the liquid storage of boar spermatozoa: a comparison of methods. Acta Vet Hung, 58:105-116.

Gadea J. 2005. Sperm factors related to in vitro and in vivo porcine fertility. Theriogenology, 63:431-444.

Garcia EM, Vázquez JM, Calvete JJ, Sanz L, Caballero I, Parrilla I, Gil MA, Roca J, Martinez EA. 2006. Dissecting the protective effect of the seminal plasma spermadhesin PSP-I/PSP-II on boar sperm functionality. Andrology, 27:434-43.

Garcia EM, Calvete JJ, Sanz L, Roca J, Martinez AE, Vazquez MJ. 2009. Distinct effect of boar seminal plasma fractions exibiting different protein profiles on the functionality of highly diluted boar spermatozoa. Reprod Domest Anim, 44:200-205.

Gerrits RJ, Lunney JK, Johnson LA, Vernon GP, Kraeling RR, Rohrer GA. 2005. Perspectives for artificial insemination and genomics to improve global swine populations. Theriogenology, 63:283-299.

González-Cadavid V, Martins MAJ, Moreno BF, Andrade ST, Santos LCA, Cristina A, MonteiroMoreira O, Moreira AR, Moura AA. 2014. Seminal plasma proteins of adult boars and correlations with sperm parameters. Theriogenology, 82:697-707.

Kommisrud E, Paulenz H, Sehested E, Grevle IS. 2002. Influence of boar and semen parameters on motility and acrosome integrity in liquid boar semen stored for five days. Acta Vet Scand, 43:49-55.

Leahy T, Gadella MB. 2011. Sperm surface changes and physiological consequences induced by sperm handling and storage(. Reproduction, 142:759-778.

Lipenský J, Lustyková A, Frydrychová S, Rozkot M, Václavková E. 2013. Influence of different extenders, dilution rate and storage time on boar sperm progressive motility. Res Pig Breed, 7:38-42.

Maxwell WMC, Johnson AL. 1999. Physiology of spermatozoa at high dilution rates: the influence of seminal plasma. Theriogenology, 52:1353-1362.

Maxwell WMC, de Graaf SP, Ghaoui RE-H, Evans G. 2007. Seminal plasma effects on sperm handling and female fertility. Soc Reprod Fertil, (suppl 64):13-38. Mogielnicka-Brzozowska M, Kordan W. 2011. Characteristics of selected seminal plasma proteins and their application in the improvement of the reproductive processes in mammals. Pol J Vet Sci, 14:489-499.

Moore MHD, Hibbit GK. 1976. The binding of 
labeled basic proteins by boar spermatozoa. $J$ Reprod Fertil, 46:71-76.

Nasrin SJ, Calogero S. 2012. Seminal plasma: an essential attribute to spermatozoa (a review). J Androl, 33:536-551.

Novak S, Ruiz-Sanchez A, Dixon TW, Foxcroft RG, Michael GR, Dyck K. 2010. Seminal plasma proteins as potential markers of relative fertility in boars. $J$ Androl, 31:188-200.

Stančić B, Grafenau P, Radović I, Petrović M, Božić A. 2009. Intensity of boar sperm utilization in Vojvodina and possibility of its increase. Contemp Agric (Novi Sad, Serbia), 58:19-26.

Stančić I, Dragin S, Stanković B, Jotanović S. 2012. Effect of protein contents in seminal plasma on sperm motility in diluted boar semen. In: Proceedings of 1st International Symposium on Animal Science, 2012, Belgrade Serbia. Belgrade: ISAS. pp. 149-154.

Strzezek J, Wysocki P, Kuklinska M. 2005. Proteomiks of boar seminal plasma - current studies and possibility of their application in biotechnology of animal reproduction. Reprod Biol, 5:279-290.

Tanavots A, Kaart T, Saveli O. 2002. Artificial insemination in pig breeding in Estonia. Vet Zootech, 19:109-111.

Tummaruk P, Luneheim N, Einarsson S, Dalin A-M. 2000. Reproductive performance of purebred Swedish Landrace and Swedish Yorkshire sows: II. Effect of mating type, weaning-to-first-service interval and lactation length. Acta Agric Scand, Sect A, Anim Sci, 50:217-224.

Waberski D, Meding S, Dirksen G, Weitze KF, Leiding C, Hahn R. 1994. Fertility of long-term-stored boar semen: Influence of extender (Androhep and Kiev), storage time and plasma droplets in the semen. Anim Reprod Sci, 36:145-151.

Waberski D, Henning H, Petrunkina MA. 2011. Assessment of storage effects in liquid preserved boar semen. Reprod Domest Anim, 46(suppl 2):45-48.

Wolf J, Smital J. 2009. Quantification of factors affecting semen traits in artificial insemination boars from animal model analyses. J Anim Sci, 87:1620-1627. 